Environmental Research Journal 5 (4): 170-172, 2011

ISSN: 1994-5396

(C) Medwell Journals, 2011

\title{
Evaluation of the Radiation Dose from Radon Ingestion and Inhalation in Water Supplies of Sadatshahr and Javaherdeh in Iran
}

\author{
Z. Pourhabib, A. Binesh and H. Arabshahi \\ Department of Physics, Payame Noor University, Fariman, Iran
}

\begin{abstract}
Radon is an odorless, radioactive gas formed from the breakdown of uranium and thorium. Chronic exposure to elevated radon $\left({ }^{222} \mathrm{Rn}\right)$ decay product concentrations is recognized as health risk. The water used for drinking and other household uses can increase the indoor radon level because dissolved radon escapes from the water and gets into household air in the course of dishwashing showering and other water-using activities. Also, ingesting water with elevated levels of radon can present a risk for developing internal organ cancers. In this study radon concentrations of the 43 water samples have been measured by PRASSI system. The 4 samples have radon concentration higher than $11 \mathrm{~Bq} \mathrm{~L}^{-1}$ as normal level. Similarly, the annual effective dose in stomach and lung per person has been evaluated in this research. According to the advised of WHO and the EU council none of the samples induced the total annual effective dose $>0.1 \mathrm{mSv}_{\text {year }}{ }^{-1}$.
\end{abstract}

$\underline{\text { Key words: Radon, effective dose, drinking water, PRASSI system, Sadatshahr and Javaherdeh regions, Iran }}$

\section{INTRODUCTION}

Radon is a colorless, odorless, tasteless, naturally occurring radioactive gas produced from the decay of the element radium which occurs naturally in rocks and soil worldwide. The radon readily escapes from the soil or rock where it is generated and enters surrounding water or air. This colorless, odorless and chemically inactive gas is 7.6 times heavier than air; it readily dissolves in water particularly if water is slightly acidic and not rich in minerals and in alcohol and fatty acids (Zdrojewicz and Strzelczyk, 2006). High radon concentration in indoor air coupled with the prolonged exposure periods related to indoor habitation make indoor radon a potential hazard (Mohamed et al., 2008). Radon and its daughters emit alpha, beta and gamma radiations as they decay. Internally deposited alpha radiations are the most damaging as their relative biological effectiveness is about 20 times that of beta radiations (Virk and Sharma, 2000). These inhaled solid radon decay products deliver the radiologically significant dose to the lung tissues (Field, 2001) that can hurt lung tissue lead to lung cancer.

Radon in water can follow two different paths to enter the human body. Firstly, radon can escape from household water and become a source for indoor radon which can then enter the human body through the respiratory tract to deliver the radiation dose. Secondly, radon in drinking water or mineral drinks can enter the human body directly through the Gastro-Intestinal (GI) tract and deliver a whole body radiation dose, the largest dose being received by the stomach (Tayyeb et al., 1998).

\section{MATERIALS AND METHODS}

The water samples were collected in various points distributed in and around the Sadatshahr and Javaherdeh regions. Water sampling has been done from each water supply including wells and rivers and springs as well as from household water. The samples were collected from the active wells selected for sampling, rivers and surface water reservoirs, springs as well as from domestic water taps of high consumption rates, $150 \mathrm{~mL}$ water samples were collected from each source or region. The collected samples were then transferred to the laboratory of Payame Noor University for analysis. Radon of water samples that have been measured using PRASSI system includes a $\mathrm{ZnS}(\mathrm{Ag})$ scintillation detector.

PRASSI system and set up of measurement: The PRASSI (Portable Radon Gas Surveyor SILENA) Model 5S has been use for radon concentration measurement in water. This system is particularly well suited for this kind of measurement that must be performed in the closed loop circuit. PRASSI pumping circuit operates with constant fallow rate at $3 \mathrm{~L} \mathrm{~min}{ }^{-1}$ in order to degassing the water sample properly. Figure 1 shows the system set up of measurement including bubbler and drier column.

Corresponding Author: Z. Pourhabib, Department of Physics, Payame Noor University, Fariman, Iran 
Numbers shown by the device is based on $\mathrm{Bq} \mathrm{m}^{-3}$. Using relationship Eq. 1, radon gas density is calculated based on $\left(\mathrm{Bq} \mathrm{L}^{-1}\right)$ :

$$
\mathrm{Q}_{\mathrm{m}}(\mathrm{Bq} / \mathrm{L})=\mathrm{Q}_{\text {PRASSI }} \times \mathrm{V}_{\text {tot }}\left(\mathrm{m}^{3}\right) / \mathrm{V}(\mathrm{lit}) \times[\exp
$$$$
(\operatorname{Ln} 2 / 3.824 \times 24) \Delta t \rrbracket
$$

Where:

$\mathrm{Q}_{\text {PRASSI }}=$ The value recorded by the device

$\mathrm{V}_{\text {tot }}=$ The total volume of air connections

$\mathrm{V}=$ The volume sample and within the brackets is a correction factor in the delay measurement

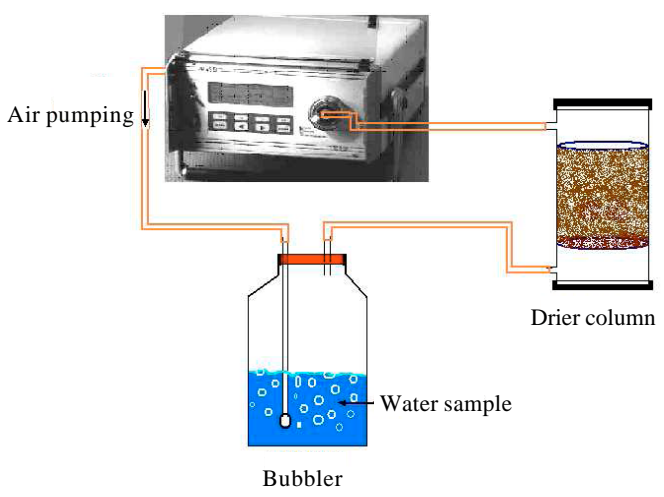

Fig. 1: The PRASSI system set up for radon measuring in the water sample

\section{RESULTS AND DISCUSSION}

In this study radon concentration in the 43 water sources of Sadatshahr and Javaherdeh regions has been measured. US EPA proposed regulations on radon concentration in drinking water: a Maximum Contaminant Level (MCL: $11 \mathrm{~Bq} \mathrm{~L}^{-1}$ ) and an alternative maximum contaminant level (AMCL: $148 \mathrm{~Bq} \mathrm{~L}^{-1}$ ) (Ishikawa et al., 2005). The third column of Table 1 shows the concentration of radon in water samples. The results in this study show 4 samples (No. 4, 8, 13, 30) have radon concentration higher than normal level. According to the data, the minimum and maximum radon concentrations in samples are 0.000 and $21.291 \mathrm{~Bq} \mathrm{~L}^{-1}$, respectively. The mean radon concentration for samples is $4.183 \mathrm{~Bq} \mathrm{~L}^{-1}$. It is believed that waterborne radon may cause higher risk than all other contaminants combined appearing in water (Savidou et al., 2001). This element enters human body through ingestion and through inhalation as radon is released from water to indoor air. Therefore, radon in water is a source of radiation dose to stomach and lungs. The annual effective doses for ingestion and inhalation were calculated according to parameters introduced by UNSCEAR report. For ingestion, the following parameters were used:

Table 1: Average radon concentration data and annual effective dose of different water sources of Sadatshahr and Javaherdeh

\begin{tabular}{|c|c|c|c|c|}
\hline \multirow[b]{2}{*}{ Water samples } & \multirow[b]{2}{*}{ Source or place of sampling } & \multirow[b]{2}{*}{ Average radon level $\left(\mathrm{Bq} \mathrm{L}^{-1}\right)$} & \multicolumn{2}{|c|}{ Annual effective dose of adults ( $\mu$ Sv y ear ${ }^{-1}$ ) } \\
\hline & & & Stomach & Lung \\
\hline 1 & Spring near Nesarood river & 2.594 & 0.467 & 6.4850 \\
\hline 2 & Bamsi spring & 1.489 & 0.268 & 3.7230 \\
\hline 3 & Safarood spring & 2.610 & 0.470 & 6.5250 \\
\hline 4 & Abmadan spring & 19.573 & 3.523 & 48.9330 \\
\hline 5 & Javaherdeh spring & 1.810 & 0.326 & 4.5250 \\
\hline 6 & Latmahale spring & 0.000 & 0.000 & 0.0000 \\
\hline 7 & Sadatshahr hot spring (No. 1) & 5.490 & 0.988 & 13.7250 \\
\hline 8 & Sadatshahr hot spring (No. 2) & 14.751 & 2.655 & 36.8780 \\
\hline 9 & Sangb one hot spring & 4.991 & 0.898 & 12.4780 \\
\hline 10 & Katolom hot spring & 5.266 & 0.948 & 13.1650 \\
\hline 11 & Markooh hot spring & 4.751 & 0.855 & 11.8780 \\
\hline 12 & Bamsi river & 1.333 & 0.240 & 3.3330 \\
\hline 13 & Abmadan river (Javaherdeh) & 21.291 & 3.832 & 53.2280 \\
\hline 14 & Javaherdeh river & 7.125 & 1.283 & 17.8130 \\
\hline 15 & Dashtejalami river & 2.958 & 0.532 & 7.3950 \\
\hline 16 & Katalom river & 1.973 & 0.355 & 4.9330 \\
\hline 17 & Markooh river (No. 1) & 1.015 & 0.183 & 2.5380 \\
\hline 18 & Markooh (No. 2) environs of Ramsar city & 1.230 & 0.221 & 3.0750 \\
\hline 19 & Chalakrood river & 2.457 & 0.442 & 6.1430 \\
\hline 20 & Nesarood river & 1.298 & 0.234 & 3.2450 \\
\hline 21 & Javaherdeh drinking water (No. 1) & 0.000 & 0.000 & 0.0000 \\
\hline 22 & Javaherdeh drinking water (No. 2) & 3.179 & 0.572 & 7.9480 \\
\hline 23 & Javaherdeh drinking water (No. 3) & 3.725 & 0.671 & 9.3130 \\
\hline 24 & Javaherdeh drinking water (No. 4) & 1.263 & 0.227 & 3.1580 \\
\hline 25 & Javaherdeh drinking water (No. 5) & 6.153 & 1.108 & 15.3830 \\
\hline 26 & Javaherdeh drinking water (No. 6) & 3.248 & 0.585 & 8.1200 \\
\hline 27 & Javaherdeh drinking water (No. 7) & 5.285 & 0.951 & 13.2130 \\
\hline 28 & Javaherdeh drinking water (No. 8) & 3.494 & 0.629 & 8.7350 \\
\hline
\end{tabular}


Environ. Res. J., 5 (4): 170-172, 2011

\begin{tabular}{|c|c|c|c|c|}
\hline \multirow[b]{2}{*}{ Water samples } & \multirow[b]{2}{*}{ Source or place of sampling } & \multirow[b]{2}{*}{ Average radon level $\left(\mathrm{Bq} \mathrm{L}^{-1}\right)$} & \multicolumn{2}{|c|}{ Annual effective dose of adults $\left(\mu \mathrm{Sv}\right.$ year $\left.^{-1}\right)$} \\
\hline & & & Stomach & Lung \\
\hline 29 & Javaherdeh drinking water (No. 9) & 2.831 & 0.510 & 7.0780 \\
\hline 30 & Javaherdeh drinking water (No. 10) & 11.403 & 2.053 & 28.508 \\
\hline 31 & Javaherdeh drinking water (No. 11) & 2.381 & 0.429 & 5.9530 \\
\hline 32 & Javaherdeh drinking water (No. 12) & 2.789 & 0.502 & 6.9730 \\
\hline 33 & Payame noor university (Sadatshahr) & 0.000 & 0.000 & 0.0000 \\
\hline 34 & Kashani street (Sadatshahr) & 0.000 & 0.000 & 0.0000 \\
\hline 35 & Bibisekine region (Sadatshahr) & 3.383 & 0.609 & 8.4580 \\
\hline 36 & End of Kashani street (Sadatshahr) & 1.471 & 0.265 & 3.6780 \\
\hline 37 & 15 Hkordad street (No. 1) ( Sadatshahr) & 4.665 & 0.840 & 11.663 \\
\hline 38 & 15 Hkordad street (No. 2) (Sadatshahr) & 2.292 & 0.413 & 5.7300 \\
\hline 39 & Shahid dastgheyb street (Sadatshahr) & 9.189 & 1.654 & 22.973 \\
\hline 40 & Shahid dastgheyb street, yas alley (Sadatshahr) & 1.413 & 0.254 & 3.5330 \\
\hline 41 & End of Shahid dastgheyb street (Sadatshahr) & 2.576 & 0.464 & 6.4400 \\
\hline 42 & 15 Khordad street, golsar alley (Sadatshahr) & 1.916 & 0.345 & 4.7900 \\
\hline 43 & End of 15 khordad street (Sadatshahr) & 3.225 & 0.581 & 8.0630 \\
\hline
\end{tabular}

- The effective dose coefficient from ingestion equals $3.5 \mathrm{nSv} \mathrm{BqL}^{-1}$

- Annual intakes by infants, children and adults are found to be about 100,75 and $50 \mathrm{~L}$, respectively

- The annual effective doses due to ingestion corresponding to $1 \mathrm{~Bq} \mathrm{L^{-1 }}$ would equal $0.35 \mu \mathrm{Sv}$ year $^{-1}$ for infants, $0.26 \mu \mathrm{Sv}$ year $^{-1}$ for children and $0.18 \mu \mathrm{Sv}$ year ${ }^{-1}$ for adults

For inhalation, the following parameters were used:

- Ratio of radon in air to radon in tap water supply is in the range of $10^{-4}$

- Average indoor occupancy time per person is about 7000 h year $^{-1}$

- Equilibrium factor between radon and its progeny is equal to 0.4

- Dose conversion factor for radon exposure is 9 $\mathrm{nSv} /\left(\mathrm{Bq} \cdot \mathrm{h} \mathrm{m}^{3}\right)$

The annual effective dose due to inhalation corresponding to the concentration of $1 \mathrm{~Bq} \mathrm{~L}^{-1}$ in tap water is $2.5 \mu \mathrm{Sv}$ year $^{-1}$. Therefore, waterborne radon concentration of $1 \mathrm{~Bq} \mathrm{~L}^{-1}$ causes total effective dose of about $2.68 \mu \mathrm{Sv}$ year $^{-1}$ for adults. The mean annual effective dose per person for adults caused by different water samples are shown in Table 1. According to the advised of $\mathrm{WHO}$ and the EU council none of the samples induced the total annual effective dose $>0.1 \mathrm{mSv}_{\text {year }}{ }^{-1}$.

\section{CONCLUSION}

In this study the results show 4 samples have radon concentration $>11 \mathrm{kBq} \mathrm{L}^{-1}$ as normal level. Therefore, radon and concentration in the water of the regions is not high and this is appropriate. None of the samples induced the total annual effective dose $>0.1 \mathrm{mSv} \mathrm{year}^{-1}$ that advised by WHO and the EU council.

\section{REFERENCES}

Field, R.W., 2001. A review of residential radon casecontrol epidemiologic studies performed in the United States. Rev. Environ. Health, 16: 151-167.

Ishikawa, T., S. Yoshinaga and S. Tokonami, 2005. Airborne and waterborne radon concentrations in houses with the use of groundwater. Int. Congr. Ser., 1276: 301-302.

Mohamed A., A.A. Ahmed, A.E. Ali and M. Yuness, 2008. Attached and unattached activity size distribution of short-lived radon progeny $\left({ }^{214} \mathrm{~Pb}\right)$ and evaluation of deposition fraction. J. Nucl. Radiat. Phys., 3: 101-108.

Savidou, A., G. Sideris and N. Zouridakis, 2001. Radon in public water supplies in Migdonia Basin, central Macedonia, northern Greece. Health Phys., 80: 170-174.

Tayyeb, Z.A., A.R. Kinsara and S.M. Farid, 1998. A study on the radon concentrations in water in Jeddah (Saudi Arabia) and the associated health effects. J. Environ. Radioact., 38: 97-104.

Virk, H.S. and N. Sharma, 2000. Indoor radon levels and inhalation doses to population in Punjab. Curr. Sci., 78: 1418-1420.

Zdrojewicz, Z. and J.J. Strzelczyk, 2006. Radon treatment controversy. Dose Response, 4: 106-118. 